\title{
BROCCOLI PRODUCTION IN FUNCTION OF DOSES SULFUR IN COVERAGE
}

\author{
Carla Corrêa $^{1}$, Aline Gouveia ${ }^{1}$, Antonio Cardoso ${ }^{1}$ \\ ${ }^{1}$ São Paulo State University. PhD in Agronomic Sciences. E-mail: cvcorrea1509@gmail.com; \\ alinemendesgouveia@gmail.com; antonio-ismael.cardoso@unesp.br
}

\begin{abstract}
The objective of this research was to evaluate the effect of sulfur doses in coverage in the production of Avenger ${ }^{\circledR}$ hybrid broccoli. Five treatments were evaluated, that is, five doses of $\mathrm{S}$ in the coverage fertilization. $\left(0 ; 31 ; 62 ; 93\right.$; and $\left.124 \mathrm{~kg} \mathrm{ha}^{-1}\right)$. The experimental design was randomized blocks with 15 plants per plot, with 9 plants being evaluated. It was observed that the sulfur doses influenced the characteristics evaluated with linear effect for inflorescence fresh weight, diameter, height and fresh weight of leaves, with increase of $15.7 \mathrm{~g} ; 0.29 \mathrm{~cm} ; 0.46 \mathrm{~cm}$, and $11.9 \mathrm{~g}$ per $10 \mathrm{~kg}$ of sulfur, respectively. There was no statistical difference in the number of leaves per plant with an average of 25 .
\end{abstract}

Keywords: Brassica oleracea var. italica, ammonium sulfate, fertilizer

\section{PRODUÇÃO DE BRÓCOLIS EM FUNÇÃO DAS DOSES DE ENXOFRE EM COBERTURA}

\section{RESUMO}

Objetivou-se com esta pesquisa avaliar o efeito de doses de enxofre em cobertura na produção de brócolis híbrido Avenger ${ }^{\circledR}$. Foram avaliados cinco tratamentos, ou seja, cinco doses de $\mathrm{S}$ em cobertura $\left(0 ; 31 ; 62 ; 93 ; \mathrm{e} 124 \mathrm{~kg} \mathrm{ha}^{-1}\right)$. O delineamento experimental foi em blocos casualizados com 15 plantas por parcela, sendo 9 plantas avaliadas. Observou-se que as doses de enxofre influenciaram as características avaliadas com efeito linear para massa fresca, diâmetro, altura da inflorescência e massa fresca das folhas, com aumento de 15,7 g; 0,29 cm;0,46 cm e 11,9 g para cada $10 \mathrm{~kg}$ de enxofre, respectivamente. Não foi observada diferença estatística para o número de folhas com média de 25 folhas por planta.

Palavras-chave: Brassica oleracea var. italica, sulfato de amônia, adubação 


\section{INTRODUCTION}

Broccoli (Brassica oleracea var. italica) belongs to the Brassicaceae family (cole crops), which also comprises cabbages, kales, cauliflowers, chards, arugulas, turnips, radishes, among others; being one of the most diversified families and cultivated in large scale in Brazil (FILGUEIRA,2013). It can be compared to the cauliflowers, both presenting a greater adaptability related to environment conditions like the weather.

The first description of broccoli, also known in Brazil as "brócolo", "couve-brócolos", or "couve-brócoli" was made by Dalechamp in the $16^{\text {th }}$ century (NIEUWHOF, 1969). Previous records are not conclusive, once the term "broccoli", with Italian origins, originally nominated the side ramifications of many species of the Brassica genre used for feeding. In England this term can name other winter cauliflowers, especially annual ones, belonging to B. oleracea var. botrytis. The plant was originated from the selection and accumulation of mutations occurred during the domestication process of B. sylvestris, found on the Mediterranean region, mainly in Italy (SILVA, 2014).

However, according to Malavolta \& Morais (2007), it can be considered less demanding than cauliflowers, about the type of soil as well as the plants nutrition, highlighting its preference for sandy-clay soils, with great macro and micronutrients levels. Two types of cultivars are used: "Ramoso" and "Single Inflorescence". The "Ramoso" type produces one inflorescence and the "Single Inflorescence" type presents a central inflorescence of big size, able to reach an average of 400 grams, being more compact and presenting smaller buds than "Ramoso" type. Both are formed by small flower buds still closed, dark-green colored and with tender stems.

Even with the most part of Brazilian soils being low in sulfur and organic matter, few works were conducted with the intention of verifying the cole crops response to sulfur (CORRÊA et al., 2013). The most part of sulfur is found in the organic form (95\%). Other sulfur sources are the fertilizers, mainly in the form of sulfate and gypsum (RAIJ et al., 1997).

According to Zehler et al. (1989), although long-time known as essential to the plants, little atention was given to this nutrient, due to the symptoms of deficiency in plants were not often seen. However, since concentrated fertilizers does not have sulfur, it has been happening a decrease in the application of this nutrient in the soil and the lack of attendance to the necessity of sulfur from the plants is becoming problematic. Altogether, it can be said that the sulfur demand from the plants is the same for the phosphorus, with an average of 10 to $80 \mathrm{~kg} \mathrm{ha}^{-1}$. There are many differences 
about the demand of sulfur between cultures, for instance, the Bracicaceae, which demand a lot of sulfur (SCHONHOLF et al., 2007).

Although it is considered a secondary macronutrient, it can be noted that in many plants with economic interest, the quantities of this nutrient extracted overcome the phosphorus quantities. An example of this extraction relation is the cabbage, in which can be extracted about $64 \mathrm{~kg} \mathrm{ha}^{-1}$ of sulfur and approximately $31 \mathrm{~kg} \mathrm{ha}^{-1}$ of phosphorus, for a production of 84 ton ha $^{-1}$ (YAMADA et al., 2007).

Onward the lack of researches, the objective of this work was to evaluate the effect of sulfur doses in coverage in the production of broccoli.

\section{MATERIAL AND METHODS}

The experiment was conducted at the municipality of São Manuel, São Paulo state, Brazil ( $22^{\circ} 46^{\prime}$ latitude South, $48^{\circ} 34^{\prime}$ longitude West, and $740 \mathrm{~m}$ of altitude). The dominant climate, according to the Köppen classification, is the type $\mathrm{Cfa}$, humid hot temperate (mesothermal); the mean temperatures of the hottest month are superior to $22^{\circ} \mathrm{C}$ and of the coldest month is $17,5^{\circ} \mathrm{C}$ (CUNHA \& MARTINS, 2009), with mean annual rainfall of $1445 \mathrm{~mm}$.

The soil is Typical Dystrophic Red Latosoil (EMBRAPA, 2018). The main chemical characteristics of the soil were evaluated from samples collect at different spots, taking from the soil at a depth of $0-20 \mathrm{~cm}$. The results of the chemical analysis of soil were: $\mathrm{pH}_{(\mathrm{CaCl} 2)}$ : 6,0; organic matter $10 \mathrm{~g} \mathrm{dm}^{-3} ; \mathrm{P}_{\text {resina: }}: 90 \mathrm{mg} \mathrm{dm}{ }^{-3} ; \mathrm{H}+\mathrm{Al}: 14$ mmol $_{\mathrm{c}} \mathrm{dm}^{-3} ; \mathrm{K}: 3,2 \mathrm{mmol}_{\mathrm{c}} \mathrm{dm}^{-3} ; \mathrm{Ca}: 24 \mathrm{mmol}_{\mathrm{c}}$ $\mathrm{dm}^{-3}$; Mg: 8 mmol $_{\mathrm{c}} \mathrm{dm}^{-3}$; SB: 35; CEC: 49; V: 72\%; and S: 4,0 mmol $_{\mathrm{c}} \mathrm{dm}^{-3}$. In this way, based on the recommendations of Raij et al. (1997), there were applied $60 \mathrm{~kg} \mathrm{ha}^{-1}$ of nitrogen, $200 \mathrm{~kg} \mathrm{ha}^{-1}$ of phosphorus $\left(\mathrm{P}_{2} \mathrm{O}_{5}\right)$ and $120 \mathrm{~kg} \mathrm{ha}^{-1}$ of potassium $\left(\mathrm{K}_{2} \mathrm{O}\right)$ in the plantation fertilization and $50 \mathrm{tha}^{-}$ ${ }^{1}$ of organic compound in total area of the seedbeds $(0,2 \mathrm{~m}$ high).

The sowing was held in 06/03/2014 in polypropylene trays with 200 cells, filled with coirbased substrate. The transplant was conducted in 26/03/2014, with spacing of $0.5 \times 0.4 \mathrm{~m}$. The culture treating comprised the weeding and the irrigation by sprinkling.

Five treatments were evaluated, that is, five doses of $S$ in the coverage fertilization. $(0 ; 31$; 62; 93; and $124 \mathrm{~kg} \mathrm{ha}^{-1}$ ). The experimental design was randomized blocks with 15 plants per plot, with 9 plants being evaluated. 
The sulfur coverage fertilization was made according to the treatments at 15,30 and 45 days after the transplant, besides $108 \mathrm{~kg} \mathrm{ha}^{-1}$ of $\mathrm{N}$ and $90 \mathrm{~kg} \mathrm{ha}^{-1}$ of $\mathrm{K}_{2} \mathrm{O}$ in agreement with the recommendations of Raij et al., (1997). The sulfur source used was the ammonium sulfate (22 $24 \%$ of $\mathrm{S}$ and $20 \%$ of $\mathrm{N}$ ), with the remaining of $\mathrm{N}$ completed with urea.

Right after the harvest, there were evaluated the fresh weight, height and diameter of the inflorescence, as well as the number and fresh weight of leaves. For the mass attainment it was used a semi-analytical scale, expressing the values in grams per plant; for the diameter it was used a digital calliper, with the results expressed in centimeters; and for the height it was used a centimeter-graduated ruler.

The data were submitted to analysis of regression for the doses of S, using the statistical program Sisvar 5.6 (FERREIRA, 2015).

\section{RESULTS AND DISCUSSION}

Statistical difference was observed for all characteristics related to inflorescence (fresh weight, diameter and height), for fresh weight of leaves, but no for number of leaves per plant. No statistical difference was observed for the number of leaves per plant with means of 25 . These values were similar to those found by Ferreira et al. (2013), who observed means of 24 leaves when evaluating doses of bokashi in broccoli.

On the other hand, for the fresh weight of the leaves of the broccoli plant was observed an increase of $11.9 \mathrm{~g}$ for each $10 \mathrm{~kg} \mathrm{ha}^{-1}$ of sulfur (Figure 1), with a maximum estimated in $1097 \mathrm{~g}$ per plant for the highest dose (124 kg ha-1 of S). Comparing with control treatment (zero dose), it was obtained an increase of only $16 \%$ for the leaves fresh matter.

For inflorescence fresh weight was observed an increase of $15,7 \mathrm{~g}$ for each $10 \mathrm{~kg} \mathrm{ha}^{-1}$ of S applied in coverage (Figure 2), with a maximum estimated in $570 \mathrm{~g}$ for the highest dose (124 kg $\mathrm{ha}^{-1}$ of S). Comparing with control treatment (zero dose), it was obtained an increase in more than $50 \%$ for the inflorescence fresh matter. So the increasing in inflorescence fresh weight was much higher than for leaves, showing the importance of sulfur in coverage for broccoli production.

Sulfur is important in plant metabolism, being part of amino acids, proteins, chloroplast molecules, among other metabolic functions, which can increase in fresh weight in vegetables (SOARES et al., 2017). Schonhof et al. (2007) and Elwan et al. (2011) also related greater inflorescence fresh weight with adequate sulfur doses in broccoli. Comparing to other authors, the 
values are similar to Diniz et al. (2008), Lalla et al. (2010) and Freitas et al. (2011), who obtained maximum value ranging from 405 to $600 \mathrm{~g}$ per plant.

Figure 1. Fresh weight of the broccoli inflorescence in function of the sulfur doses in coverage. Faculdade de Ciências Agrônomicas /UNESP, Botucatu, 2014.

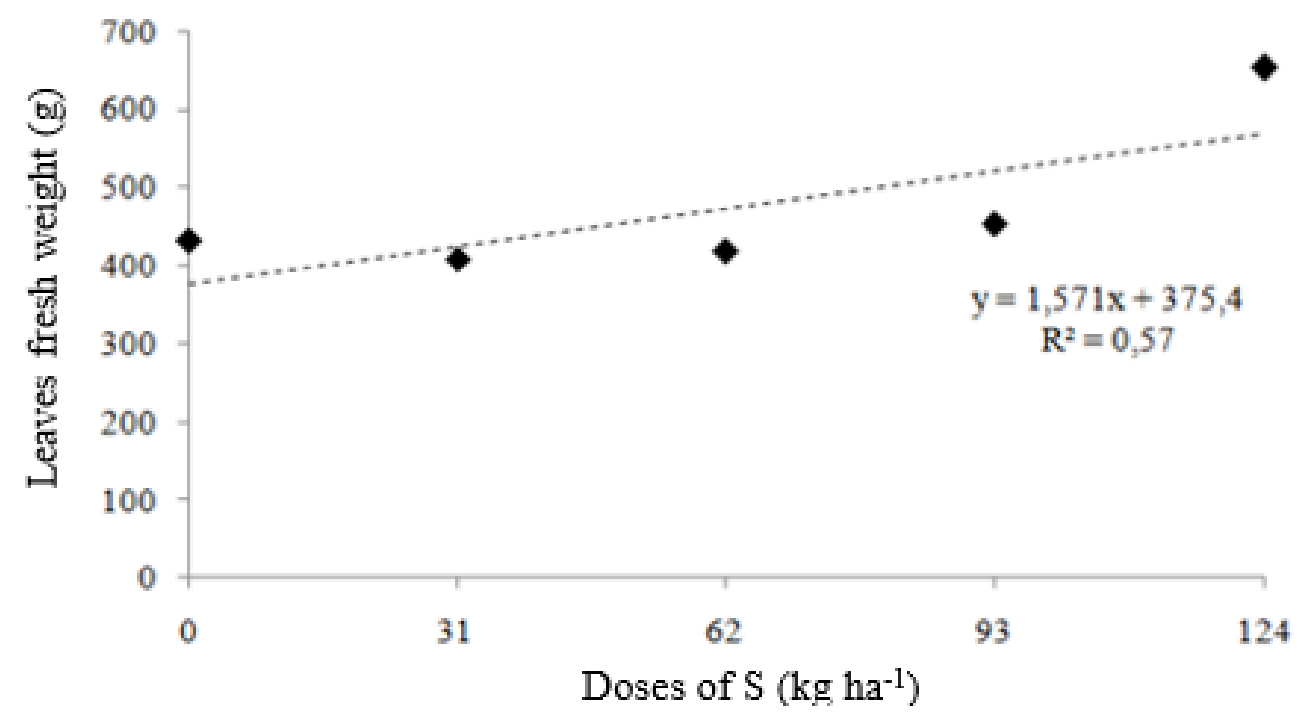

Figure 2. Broccoli inflorescence diameter in function of the sulfur doses in coverage. Faculdade de Ciências Agrônomicas /UNESP, Botucatu, 2014.

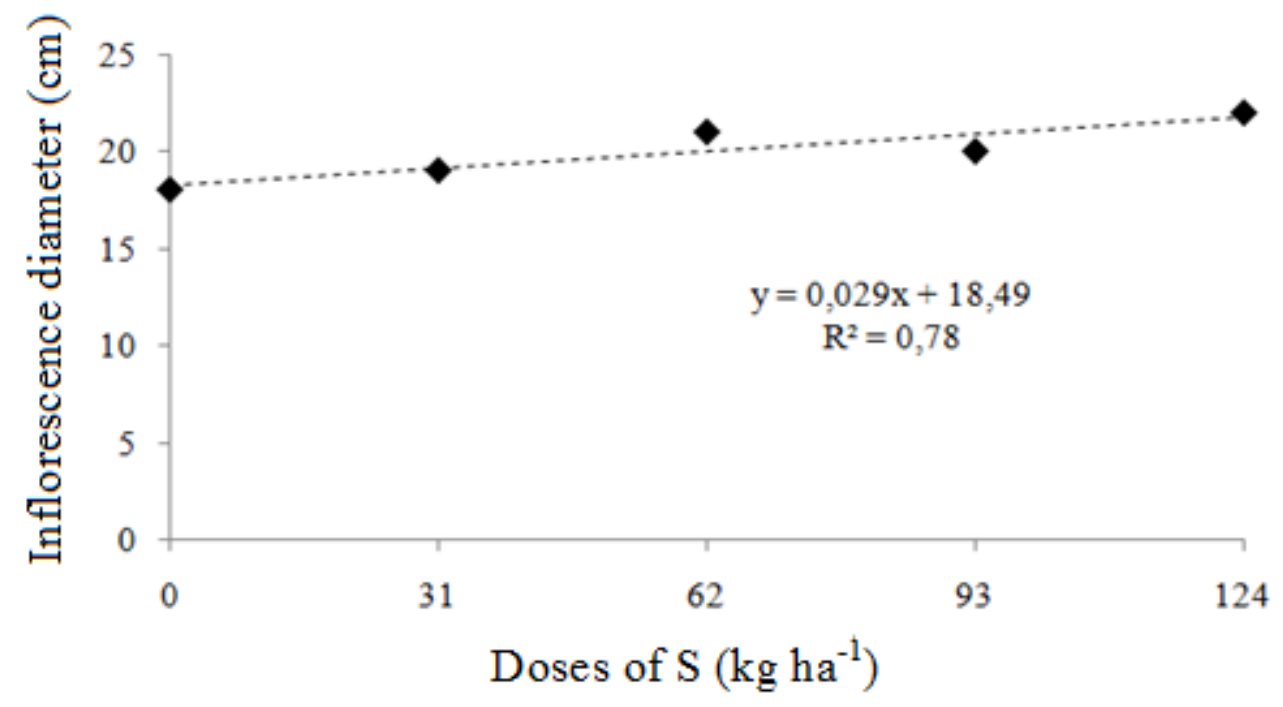

For the inflorescence diameter also was observed linear effect with increase of $0,29 \mathrm{~cm}$ for each $10 \mathrm{~kg} \mathrm{ha}^{-1}$ of sulfur in coverage (Figure 3), with maximum estimated in 22,1 cm for the highest dose (124 kg ha ${ }^{-1}$ of S). Comparing to other authors, the values are similar to Pizetta et al. (2005) 148 
and Kano et al. (2008), who obtained averages of 20.4 and $20.5 \mathrm{~cm}$, and superior to Lalla et al. (2010), $15.5 \mathrm{~cm}$.

Figure 3. Broccoli inflorescence height in function of the doses of sulfur in coverage. Faculdade de Ciências Agrônomicas /UNESP, Botucatu, 2014.

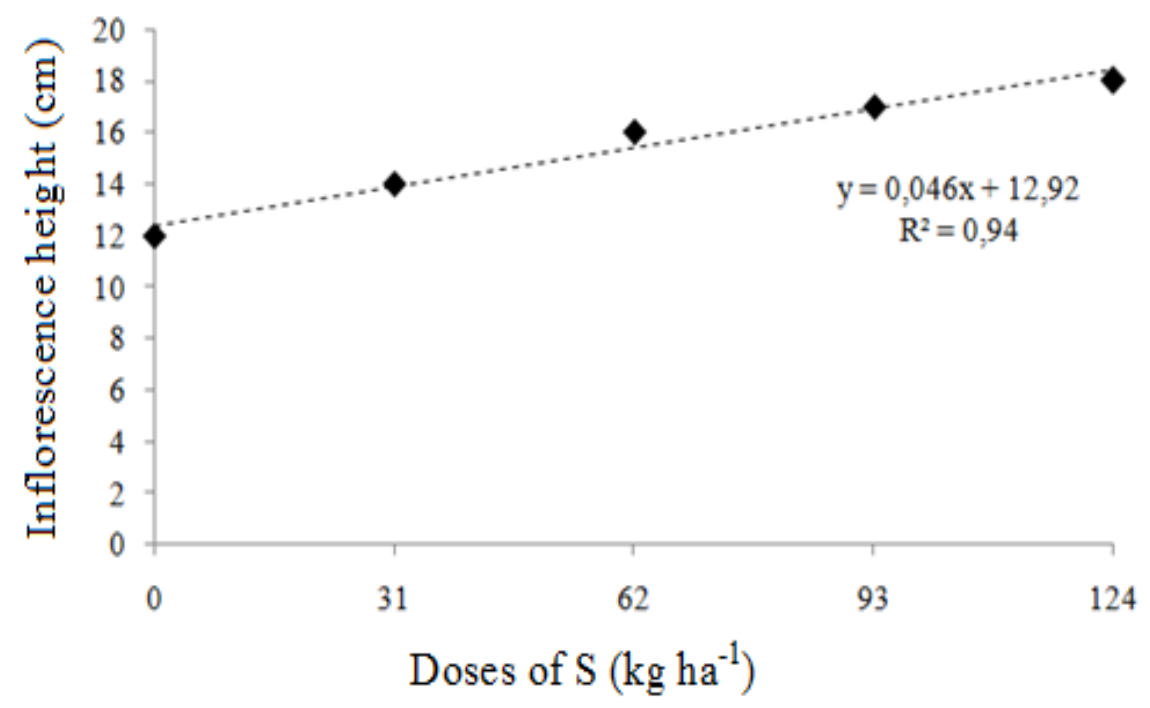

For inflorescence height it is estimated an increase of $0.46 \mathrm{~cm}$ for each $10 \mathrm{~kg} \mathrm{ha}^{-1}$ of sulfur in coverage (Figure 4), with maximum estimated in $18.6 \mathrm{~cm}$ for the highest dose $\left(124 \mathrm{~kg} \mathrm{ha}^{-1}\right.$ of S). The same behavior of all inflorescence characteristics was expected, because the greater the diameter and the height, the greater must be the weight, as observed.

The linear increasing in inflorescence fresh weight, diameter and height show the importance of sulfur for broccoli production. Sulfur performs functions that determine the increases in the production, because it is one of the components of Acetyl-CoA, which represents the "neural center" in the Krebs' cycle; is a component of ferredoxins, which are enzymatic complexes involved in the photosynthesis and in the fixation of nitrogen molecules, as well as in the chlorophyll formation (FERNANDES, 2006). It is important, also, for nitrogen fixation; chlorophyll biosynthesis; and micro and macronutrients uptake (SALVAGIOTTI et al., 2008).

Sulfur is related to the photosynthetic processes and the increase in all characteristics may be related to the photosynthesis intensity, as described by Fernandes (2006). Despite all these functions, there are few studies with sulfur. In brassica, there are reports that this nutrient are accumulated to more than twice the P levels (Yamada et al., 2007), and in seeds this nutrient is the 
second most accumulated of broccoli (Magro et al., 2010) and by cauliflower (Cardoso et al., 2016), and its application in top dressing favors the increase of seed production (CORRÊA et al. 2017).

Figure 4. Broccoli leaves fresh weight in function of the sulfur doses in coverage. Faculdade de Ciências Agrônomicas /UNESP, Botucatu, 2014.

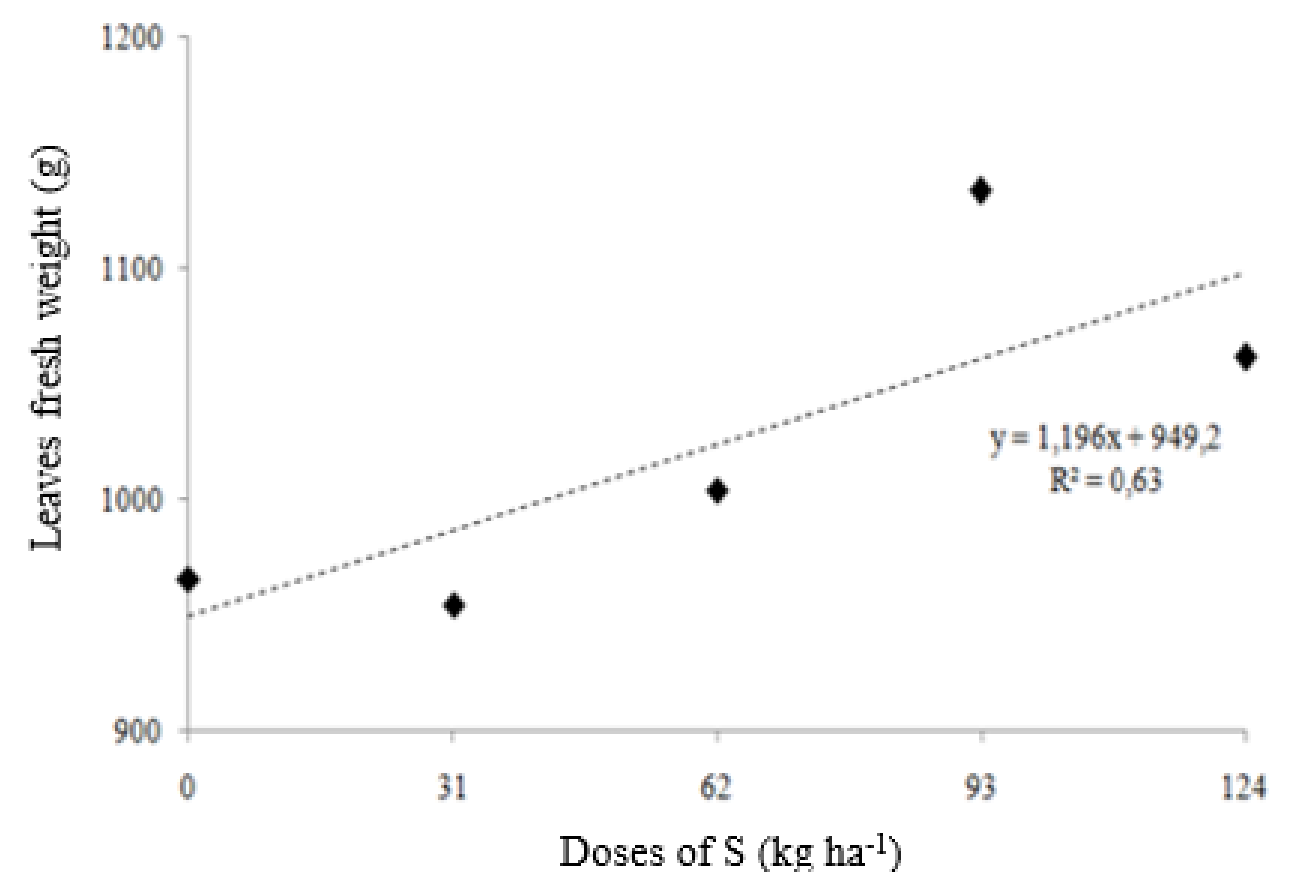

In literature, there are recommendations of fertilization with $\mathrm{S}$ for cole crops, by Raij et al. (1997) and Filgueira (2013), with 30 to $60 \mathrm{~kg} \mathrm{ha}^{-1}$ of S in the plantation, but it is not recommended in coverage and there are with few works conducted in order to verify the culture response to this nutrient. Generally, it can be stated that the sulfur demand by the plants is the same as for the phosphorus, about 10 to $80 \mathrm{~kg} \mathrm{ha}^{-1}$. There is a great difference regarding the sulfur demand within the cultures, with the Brassicacea being the most demanding of this nutrient. Despite the importance of sulfur in broccoli, there is no study on application of $S$ that gives any solid recommendation for using such nutrient and/or technique on its production (CORRÊA et al., 2017).

\section{CONCLUSIONS}

The application of cover sulfur in broccoli (Brassica oleracea var. Italica) because it is effective to increase the inflorescence characteristics as the fresh weight, the diameter and the height of the inflorescence increase, consequently increases the value of the product for marketing. 


\section{REFERENCES}

CARDOSO, A.I.I., CLAUDIO, M.T.R., MAGRO, F.O., FREITAS, P.G.N. 2016. Phosphate fertilization on production and quality of cauliflower seeds. Ciência Rural, Santa Maria, v. 46; n. 8, p. $1337-1343$.

CORRÊA, C.V; CARDOSO, A.I.I; CLÁUDIO, M.T.R., 2013.Produção de repolho em função de doses e fontes de potássio em cobertura. Semina: Ciências Agrárias, Londrina, v.34, n.5, p.2129-2138

CORREAA, C.V.; GOUVEIA, A.M.S.; LANNA, N.L.B.; MARTINS, B.N.M.; TAVARES, A.E.B.; MENDONÇA, V.Z.; CARDOSO, A.I.I.; EVANGELISTA, R.M..2017. Sulphur (S) topdressing and organic compost in the production, quality and nutrients accumulation in broccoli seeds at planting. Australian Journal of Crop Research, Austrália,V. 11, n. 5, p.542-547.

CUNHA, A. R.; MARTINS, D., 2009. Classificação climática para os municípios de Botucatu e São Manuel, SP. Irriga, Botucatu, v.14, n.1, p.1-11

DINIZ, E. R., 2008 Crescimento e produção de brócolis em sistema orgânico em função de doses de composto. Ciência e Agrotecnologia, Lavras, v. 32, n. 5, p. 1428-1434

ELWAN MWM, ABD EL-HAMED KE, 2011. Influence of nitrogen form, growing season and sulfur fertilization on yield and the content of nitrate and vitamin $\mathrm{C}$ of broccoli. Science Horticulture, Agassiz, 127(3):181-187.

EMPRESA BRASILEIRA DE PESQUISA AGROPECUÁRIA - EMBRAPA, 2018. Sistema brasileiro de classificação de solos. 5.ed. Brasília, DF, 590p.

FERNANDES, M.S, 2006. Nutrição mineral de plantas. Sociedade Brasileira de Ciências do Solo, Viçosa. 432p.

FERREIRA, D. F., 2015.SISVAR: a guide for its bootstrap procedures in multiple comparisons. Ciência e Agrotecnologia [online] (UFLA), Lavras, v.38, n.2, p.109-112.

FERREIRA, S.; SOUZA, R. J.; GOMES, L. A. A.,2013. Produtividade de brócolis de verão com diferentes doses de bokashi. Revista Agrogeoambiental, Pouso Alegre, v. 5, n. 2, caderno II, p.31-38

FILGUEIRA, F.A.R., 2013.Novo manual de olericultura: agrotecnologia moderna na produção e comercialização de hortaliças. Viçosa: UFV, 421p.

KANO, C.; GODOY A. R.; HIGUTI, A.R.O.; CASTRO, M.M.; CARDOSO, A.I.I, 2008. Broccoli production in function of tray type and seedling age. Ciencia e Agrotecnologia, v.32 n.1, p. $110-114$.

FREITAS, G. B., ROCHA, M. S., SANTOS, R. H. S., FREITAS, L. M. S., RESENDE, L. A. 2011. Produção de brócolis em resposta à adubação de cobertura com adubo verde e biofertilizante. Revista Ceres, Viçosa, v.58, n.5, p. 645-650.

LALLA, J.G.; LAURA, V.A.; RODRIGUES, A.P.D.C.; SEABRA JÚNIOR, S.; SILVEIRA, D.S.; ZAGO, V.H.; DORNAS, M.F. 2010. Competição de cultivares de brócolos tipo cabeça única em Campo Grande. Horticultura Brasileira, Brasília, 28: 360-363.

MAGRO, F.O; ARRUDA, N; CASA, J; SALATA, A.C; CARDOSO, A.I.I; FERNANDES, D.M. 2010. Composto orgânico na produção e qualidade de sementes de brócolis. Ciência e Agrotecnologia, v. 34, p. 596-602.

MALAVOLTA, E.; MORAES, M.F. Fundamentos do nitrogênio e do enxofre na nutrição mineral das plantas cultivadas. In: YAMADA, T.; ABDALLA, S.R.S. e; VITTI, G.C. (Ed.). Nitrogênio e enxofre na agricultura brasileira. Piracicaba: IPNI Brasil, 2007. p.189249. 
NIEUWHOF, M., 1969. Cole Crops. London, Leonard Hill, 353p.

PIZETTA, L.C.; FERREIRA, M.E.; CRUZ, M.C.P.; BARBOSA, J.C. 2005. Resposta de brócolis, couve-flor e repolho à adubação com boro em solo arenoso. Horticultura Brasileira, Brasília, 23: 51-56.

RAIJ, B. Van; CANTARELLA, H.; QUAGGIO, J.A.; FURLANI, A.M.C., 1997.Recomendações de adubação e calagem para o Estado de São Paulo. 2. ed. Campinas: Instituto Agronômico \& Fundação IAC, 285p.

SALVAGIOTTI, F., CASSMAN K. G., SPECHT, J. E., WALTERS D. T., WEISS, A., DOBERMANN, A. 2008. Nitrogen uptake, fixation and response to fertilizer $\mathrm{N}$ in soybeans: A review. Field Crops Research, Netherlands, 108 (1), pp. 1 -13.

SCHONHOF I, BLANKENBURG D, MUELLER S, KRUMBEIN A (2007). Sulfur and nitrogen supply influence growth, product appearance, and glucosinolate concentration of broccoli. Journal Plant Nutrition Soil Science, Weinheim, 170(1):1-8.

SILVA, N., 2014. Melhoramento de brássicas no Brasil. www.sbmp.org.br/cbmp2001/palestras/palestra16.htm

SOARES, M.M., BARDIVIESSO, D.M., BARBOSA, W.F.S., BARCELOS, M.N. 2017. Adubação de cobertura com enxofre na cobertura da rúcula. Revista de Agricultura Neotropical, Cassilândia, v.4, n.1, p.49-52.

YAMADA, T; ABDALA, S.R.S; VITTI, G.C., 2007. SIMPÓSIO SOBRE NITROGÊNIO E ENXOFRE NA AGRICULTURA BRASILEIRA., Anais... IPNI, Brasil, 722.p.

ZEHLER, E; KREIPE, H; GETHING, P.A., 1989.Sulfato de potássio e cloreto de potássio: sua influência na produção e na qualidade das plantas cultivadas. Campinas: Fundação Cargill, 111p. 